\title{
Determination of Entrepreneurship Education, Family Environment, and Self-Efficacy on Entrepreneurship Interest
}

\author{
Ida Ayu Putu Widani Sugianingrat ${ }^{*}$, Ida I Dewa Ayu Yayati Wilyadewi², I Wayan \\ Gde Sarmawa ${ }^{3}$ \\ ${ }^{1,2}$ Faculty of Economics and Business of the Hindu University of Indonesia-Denpasar-Bali, Indonesia \\ ${ }^{3}$ Faculty of Economics and Business of the University of Warmadewa-Denpasar-Bali, Indonesia \\ 'widanidayu47@gmail.com, ${ }^{2} w i l y a d e w i @ y a h o o . c o m,{ }^{3}$ wayangdesarmawa@gmail.com, *corresponding author
}

\begin{abstract}
This study aims to study the effect of entrepreneurship education, work environment, and selfefficacy on student interest in entrepreneurship. This research was conducted on students of the Faculty of Economics, Hindu University of Indonesia in 2016 who were taking entrepreneurship courses totaling 270 students. The number of samples is determined based on the Slovin formula with an error of $10 \%$. Based on these calculations, a total sample of 79 students was obtained. Determining students who become samples is done randomly. Data collection is done by conducting interviews directly with respondents, based on a pre-arranged questionnaire. The collected data is then tabulated, then processed using the SmartPLS 3.0 program. The results of the hypothesis testing show that entrepreneurship education and family environments have a significant positive effect on students' interest in entrepreneurship. Meanwhile, self-efficacy shows positive results but does not significantly influence the interests of students to become entrepreneurs.
\end{abstract}

Keywords: entrepreneurship education, family environment, self-efficacy, entrepreneurial interest

\section{Pengaruh Pendidikan Kewirausahaan, Lingkungan Kerja, dan Efikasi Diri terhadap Minat Mahasiswa Berwirausaha}

\begin{abstract}
Abstrak
Penelitian ini bertujuan untuk melakukan kajian pengaruh pendidikan kewirausahaan, lingkungan kerja, dan efikasi diri terhadap minat mahasiswa untuk berwirausaha. Penelitian ini dilakukan pada mahasiswa Fakultas Ekonomi Universitas Hindu Indonesia angkatan tahun 2016 yang sedang mengambil mata kuliah kewirausahaan berjumlah 270 mahasiswa. Jumlah sampel penelitian ditentukan berdasarkan rumus Slovin dengan error 10\%. Berdasarkan perhitungan tersebut diperoleh jumlah sampel sebanyak 79 mahasiswa. Penentuan mahasiswa yang menjadi sampel penelitian dilakukan secara acak. Pengumpulan data dilakukan dengan melakukan wawancara langsung kepada responden, berdasar pada kuesioner yang telah dipersiapkan. Data yang telah terkumpul selanjutnya dilakukan tabulasi, kemudian diolah dengan mempergunakan program SmartPLS 3.0. Hasil pengujian hipotesis menunjukkan pendidikan kewirausahaan dan lingkungan keluarga berpengaruh secara positif signifikan terhadap minat mahasiswa untuk berwirausaha. Sedangkan, efikasi diri menunjukkan hasil yang positif, tetapi tidak signifikan berpengaruh terhadap minat mahasiswa untuk berwirausaha.
\end{abstract}

Kata Kunci: pendidikan kewirausahaan, lingkungan keluarga, efikasi diri, minat berwirausaha

\section{INTRODUCTION}

Entrepreneurial interest in Indonesian people is still relatively weak. It can be concluded from from the proportion of entrepreneurs which only reaches $3.1 \%$, while developed countries have an average proportion of entrepreneurs of $14 \%$ (https://nasional.kompas.com/read/2018). The lower the proportion of entrepreneurs, the more limited the employment, so the unemployment rate is higher. This is in line with the condition of Indonesia, where the number of entrepreneurs is very small, so the 
unemployment rate is very high. Based on data from the Central Statistics Agency (BPS) (2019) total unemployment in Bali is 30,262 people.

The low interest of the community for entrepreneurship is influenced by a number of factors. Environmental factors (in this case the family environment) are factors that significantly influence one's interest in entrepreneurship (Hutagalung et al., 2017; Novita et al., 2017; Wiani et al., 2018; Nurmaliza et al., 2018; Periansya, 2018; Ayyubi et al., 2018). However, a number of studies also found different results, where the environment does not affect a person's interest in entrepreneurship (Sandi \& Nurhayati, 2020).

In addition to the family environment, entrepreneurship education also influences interest in entrepreneurship (Patricia \& Silangen, 2016; Periansya, 2018; Ayyubi et al., 2018; Prianto et al., 2018; Aladejebi, 2018). Effective entrepreneurship education can encourage the growth of interest in entrepreneurship. While the results of research conducted by Lekoko et al. (2012); Hutasuhut (2018); and Sandi \& Nurhayati (2020) found entrepreneurship education had no significant effect on entrepreneurial interest.

Self-efficacy is also one of the factors that contribute to the growth of interest in entrepreneurship. A number of research results have proven that confidence in the ability to manage a business can strengthen one's interest in opening a business. Sadriwala \& Kan (2018), found that self-efficacy had a significant positive effect on entrepreneurial interest. Other research results that are in line with this are Campo (2011); Shaheen \& Haddad (2018); Saraih et al. (2018); (Sandi \& Nurhayati, 2020).

A number of the results of these studies have a very strong influence on interest in entrepreneurship, so this research focuses on these factors.

\section{Entrepreneurship Interest}

Talking about entrepreneurial interests, divided into two words namely interest and entrepreneurship. Interest is defined as high interest or encouragement from someone who becomes a person to do something in order to realize the achievement of goals and ideals that become their desires which are carried out with awareness and bring feelings of pleasure and joy (Harackiewicz \& Hulleman, 2010). According to Slavin (2019), interest is one's tendency to feel attracted to a particular field and feel happy to be involved in various activities related to that field. Entrepreneurial intentions can be explained as mental states and behaviors, directing and controlling personal activities towards the improvement and implementation of new business ideas (Hattab, 2014). This entrepreneurial intention can also be defined as a commitment to start a new business (Kuratko, 2016).

The component of interest according to De Mooij (2019), consists of cognitive, affective, and conative. Cognitive is knowledge and perception obtained through experience with an object, attitude, and information from various sources. Affective describes a person's feelings and emotions towards objects. Conative, is a continuation of the two elements that are manifested in the form of the will and desire to carry out an activity.

While entrepreneurship is defined as people who have the ability to see and assess business opportunities, the resources needed to take advantage of it and take appropriate actions to ensure success (Franco, 2016). According to Kuratko (2016), entrepreneurship is 
an ability to create business activities. The ability to create and require creativity and innovation from pre-existing (Mitra, 2019).

So, the interest in entrepreneurship is someone's pleasure and interest in doing entrepreneurial activities. Interest in conducting entrepreneurial activities according to Arshad et al. (2019) can be influenced by two factors namely intrinsic and extrinsic factors. Intrinsic factors include self-efficacy, that is, one's trust/belief in himself in his ability to master and produce something (Slavin, 2019). External factors that can affect interest are education and family environment.

\section{Entrepreneurship Education}

According to Bartlett \& Burton (2016), education is a conscious effort undertaken by the family, community, and government, through mentoring, teaching and training activities that take place in school and outside of school for life, to prepare students to play a role in a variety of environments precisely in the future. Education aims to realize people who have faith, are pious, intelligent, physically and mentally healthy, have adequate skills, have a noble character, have high awareness and are always introspective, responsive to problems, able to solve problems well and rationally, and have a bright future (Rothstein \& Jacobsen, 2006; Chipman et al. (2013). According to Kalantzis \& Cope (2012), education components consist of basic education, educational goals, educators, students, educational materials, educational methods, educational tools/facilities, and educational environment. According to Gautam \& Singh (2015), entrepreneurship education in the form of knowledge and understanding of values, behaviors, and abilities regarding entrepreneurship in facing life's challenges. Mwasalwiba (2010) states, the aim of entrepreneurship education is to form individuals with character, skills, and understanding to become entrepreneurs.

Indicators of entrepreneurship education according to Braag \& Henry (2011), consist of methods used in entrepreneurship education, entrepreneurship material provided in entrepreneurship education, the purpose of teaching entrepreneurship education in fostering entrepreneurial intentions, entrepreneurship education fosters awareness of business opportunities.

A number of research results have proven that entrepreneurial knowledge can influence entrepreneurial interests, namely Lai (2015), Dogan (2015), Hajrah \& Rahayu (2016), Mardisentosa \& Mulyasana (2018), Sudjarwo et al. (2019); Deliana et al. (2019).

Based on theoretical and empirical studies as outlined, the following research hypotheses are built:

Hypothesis 1: Entrepreneurship education has a significant positive effect on entrepreneurial interest.

\section{Family Environment}

The environment is the whole physical/natural or social phenomenon (event, situation, or condition) that affects an individual's development (Hutchison, 2018). The family is where the main activities of an individual's life take place, so the family becomes the first and main institution of human resource development (Brannen, 2019). According to Melville et al. 
(2007) families are people who have social-biological ties through marriage, birth or adoption, do not live together and use resources together to achieve common goals. Melville et al. (2007) mentions the family is the first social unit of the development of society towards a city-state. According to Sandi \& Nurhayati (2020), the family environment is the closest social environment of an entrepreneur, whose role is very large in shaping the character, including the entrepreneurial character of a child. In the family environment, a child gets inspiration and entrepreneurial support from the family, and there are activities in the family which means learning entrepreneurship.

According to Hutchison (2018), there are three main things that affect a person's development in his life, namely the functioning of the family, the attitude and treatment of parents towards children, and economic status.

The results of research that prove that the family environment significantly influences the interests of entrepreneurship, namely Rachmawan et al. (2015), Sudjarwo et al. (2019). Based on theoretical and empirical studies as described, the following research hypotheses are built:

Hypothesis 2: Family environment has a significant positive effect on entrepreneurial interest

\section{Self-efficacy}

According to Bandura (1997), self-efficacy is the belief that someone is able to carry out tasks, achieve goals and overcome obstacles in various situations. People who believe in their abilities and beliefs show good results (Fuller et al., 2018). Indicators to measure selfefficacy according to Bandura (1997) consist of levels related to the degree of difficulty of the task when individuals feel able to do it, strengths related to beliefs in individuals about their abilities, generalizations related to the behavior shown by individuals who feel confident about his abilities.

The results of the study that found a significant positive effect of self-efficacy on entrepreneurial interest found by (Naktiyok et al., 2010); König, 2012; Pihie \& Bagheri, 2013; Dogan, 2015; Rachmawan et al., 2015; Sudjarwo et al., 2019). Based on theoretical and empirical studies as described, the following research hypotheses are built:

Hypothesis 3: Self-efficacy has a significant positive effect on entrepreneurial interest.

Based on a theoretical study and support of a number of previous research findings, where entrepreneurship education, family environment, and self-efficacy are stated to be correlated significantly to the interests of entrepreneurship, the research conceptual framework was constructed as shown in Figure 1; 


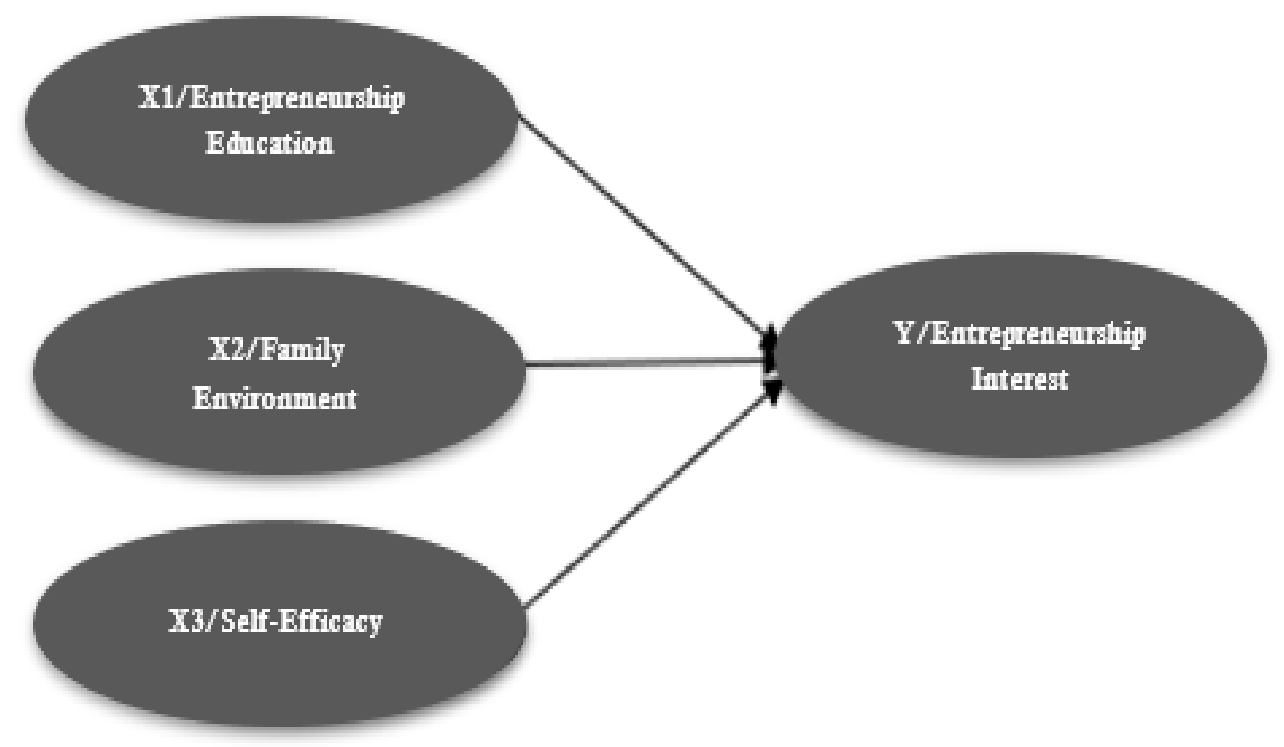

Figure 1. Research Conceptual Framework

\section{METHOD}

This study was designed in a quantitative approach by correlating entrepreneurship education, family environment, and self-efficacy, related to entrepreneurial interest. The study was conducted on 370 students from the Faculty of Economics, Business and Tourism of the Hindu University of Indonesia who were taking entrepreneurship courses. The number of research samples is determined by the Slovin formula at an error rate of $10 \%$, the formulation is as follows:

$\mathrm{n}=\mathrm{N} /\left(1+\mathrm{Ne}^{2}\right)$

$\mathrm{n}=370 /\left(1+370.10^{2}\right)$

$\mathrm{n}=78.72$ (rounded to 79$)$

then the number of research samples is 79 students. Determination of the sample, the study was conducted randomly.

Data collection was carried out by conducting direct interviews with students who were research respondents, based on a questionnaire that had been prepared. Furthermore, the data that has been collected is tabulated and analyzed with the SmartPLS 3.0 program. The stages of data processing using SmartPLS consists of three stages, namely the evaluation stage of the measurement model, the structural model evaluation, and the hypothesis testing stage. The structural model evaluation phase consists of evaluating the validity and reliability through convergent validity and discriminant validity. Stage structural model consists of model accuracy through R-Square $\left(\mathrm{R}^{2}\right)$, and Path Coefficient significance.

\section{FINDING AND DISCUSSION}

\section{Testing Validity and Reliability}

Testing the validity and reliability of research data was carried out through two criteria, namely convergent validity, and discriminant validity. Converging validity testing can be seen through the outer loading value. The indicator can be said to be valid if it has an outer 
loading value $>0.50$ and is significant. Based on the results of data processing with the SmartPLS program, the outer loading value is obtained as shown in Table 1.

Based on Table 1, it appears that the outer loading value of each indicator is greater than 0.50 and valid at $p$-value $<0.1$ so that all indicators are declared convergent valid. Table 1 also presents the reliability of research variables based on Cronbach's Alpha and Composite Reliability criteria, where Cronbach's Alpha and Composite Reliability values $>0.70$ so that they can be declared reliable.

Table 1. Results of Validity and Reliability

\begin{tabular}{|c|c|c|c|c|c|c|}
\hline Variables & Indicators & Code/Item & $\begin{array}{c}\text { Outer } \\
\text { Loading }\end{array}$ & $\begin{array}{c}\text { p-value } \\
\text { of }\end{array}$ & $\begin{array}{c}\text { Cronbach's } \\
\text { Alpha }\end{array}$ & $\begin{array}{l}\text { Composite } \\
\text { Reliability }\end{array}$ \\
\hline \multirow{5}{*}{$\begin{array}{l}\text { X1/Entrepreneurship } \\
\text { Education }\end{array}$} & \multirow{2}{*}{ Education Method } & $\mathrm{X} 1.1$ & 0.697 & 0.000 & \multirow{5}{*}{0.777} & \multirow{5}{*}{0.786} \\
\hline & & $\mathrm{X} 1.2$ & 0.678 & 0.000 & & \\
\hline & Education Materials & $\mathrm{X} 1.3$ & 0.621 & 0.000 & & \\
\hline & Education Objective & $\mathrm{X} 1.4$ & 0.658 & 0.000 & & \\
\hline & Chance Education & $\mathrm{X} 1.5$ & 0.596 & 0.000 & & \\
\hline \multirow{4}{*}{$\mathrm{X} 2$ /Family Environment } & Functioning Family & $\mathrm{X} 2.1$ & 0.851 & 0.000 & \multirow{4}{*}{0.763} & \multirow{4}{*}{0.847} \\
\hline & г unctiommg гammy & $\mathrm{X} 2.2$ & 0.894 & 0.000 & & \\
\hline & $\begin{array}{l}\text { The attitude and } \\
\text { behavior of parents }\end{array}$ & $\mathrm{X} 2.3$ & 0.801 & 0.000 & & \\
\hline & Economic Status & $\mathrm{X} 2.4$ & 0.554 & 0.003 & & \\
\hline \multirow{4}{*}{ Self-Efficacy } & Rate & $\mathrm{X} 3.1$ & 0.935 & 0.000 & \multirow{4}{*}{0.836} & \multirow{4}{*}{0,898} \\
\hline & & $\mathrm{X} 3.2$ & 0.885 & 0.000 & & \\
\hline & Strength & $\mathrm{X} 3.3$ & 0.570 & 0.000 & & \\
\hline & Generalization & X3.4 & 0.958 & 0.000 & & \\
\hline \multirow{6}{*}{ Entrepreneurship Interest } & \multirow{2}{*}{ Cognition } & Y1 & 0.833 & 0.000 & \multirow{6}{*}{0.931} & \multirow{6}{*}{0.946} \\
\hline & & $\mathrm{Y} 2$ & 0.838 & 0.000 & & \\
\hline & & Y3 & 0.924 & 0.000 & & \\
\hline & Emotions & Y4 & 0.822 & 0.000 & & \\
\hline & \multirow{2}{*}{ Desire } & Y5 & 0.894 & 0.000 & & \\
\hline & & Y5: & 0.857 & 0.000 & & \\
\hline
\end{tabular}

\section{Evaluation of Accuracy Model}

Evaluation based on the accuracy of the research model value R-square (R2), Q Square Predictive Relevance (Q2), and Goodness of Fit (GoF). Judging from the value of R2, models classified as having a high degree of accuracy, since the value of R2 of 0.798 , which means $79.8 \%$ can be explained by student interest in entrepreneurship education, family environment, and self-efficacy, while $20.2 \%$ is another factor not included in the research model.

\section{Research Hypothesis Testing Research}

Hypothesis testing is based on the results of data processing with the program SmartPLS 3.0, where the results are shown in Figure 2 and Table 2.

Based on Figure 1 and Table 2 shows that entrepreneurship education has a significant positive effect on entrepreneurial interest because the path value of 0.196 with p-value 0.045 $<0.1$. These results give the sense that increasing entrepreneurship education can increase student interest in entrepreneurship. The results of this study confirmed a number of research results conducted by ( Lai, 2015; Dogan,2015; Hajrah \& Rahayu,2016; and 
Mardisentono \& Mulyasana, 2018) who found that entrepreneurial education had a significant positive effect on interest in entrepreneurship.

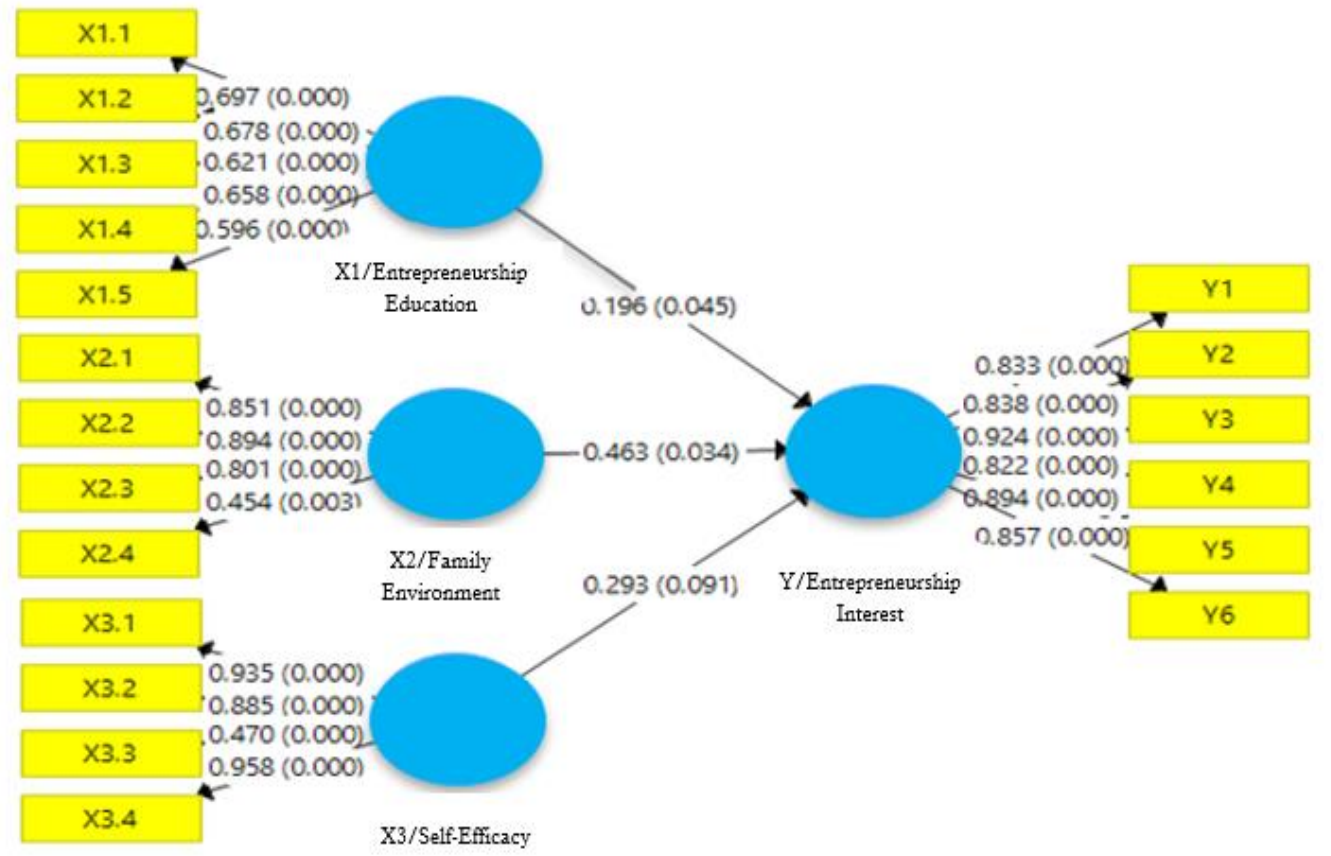

Figure 2. Test Results Relationship of Entrepreneurship Education, Family Environment, Self-Efficacy Toward Entrepreneurship Interest

Table 2. Path Coefficient of Relationship Entrepreneurship Education, Family Environment, Self Efficacy Towards Entrepreneurship Interest

\begin{tabular}{|c|c|c|c|c|}
\hline \multicolumn{2}{|c|}{ Relationship Between Variable } & \multirow{3}{*}{$\begin{array}{c}\text { Values } \\
\text { Path } \\
\text { Value }\end{array}$} & \multirow{3}{*}{$\mathrm{p}$-value } & \multirow{3}{*}{ Description } \\
\hline Indenendent Variahlec & Dependent & & & \\
\hline muependent varrables & Variables & & & \\
\hline Entrepreneurship Education & \multirow{3}{*}{$\begin{array}{l}\text { Entrepreneurship } \\
\text { Interest }\end{array}$} & 0.196 & 0.045 & H1 accepted \\
\hline Family Environment & & 0.463 & 0.034 & H2 accepted \\
\hline Self-efficacy & & 0.293 & 0.091 & H3 accepted \\
\hline
\end{tabular}

The results of the study also found (as in Figure 1 and Table 2) that the family environment significantly affected positively on student interest in entrepreneurship. This result is supported by a path value of 0.463 with a p-value of $0.034<0.1$. These results give the meaning that students' interest in entrepreneurship is greatly influenced by the family environment. The results of this study are in line with a number of previous research findings, such as those found by (Rachmawan et al., 2015; Hajrah \& Rahayu, 2016).

However, Figure 1 and Table 2 show that self-efficacy significantly influences students' interest in entrepreneurship. This is indicated from the path value of 0.293 with a $\mathrm{p}$-value of $0.091<0.1$. This means that students' interest in entrepreneurship is influenced by self-efficacy. The results of this study are in line with the results of research conducted by (Dogan, 2015; Rachmawan et al., 2015; Santoso \& Oetomo, 2018). 


\section{CONCLUSION}

Based on the results of hypothesis testing, it can be concluded that entrepreneurship education, self-efficacy, and family environment greatly affect the interests of students of the Faculty of Economics, Business, and Tourism of the Hindu University of Indonesia in entrepreneurship. Therefore, in an effort to encourage student interest in entrepreneurship, it is necessary to do entrepreneurship education more intensively, encourage increased selfconfidence, and foster entrepreneurial interest in the family environment. The education method indicator has the highest contribution to the entrepreneurship education variable, while the family environment variable, the indicator that has the highest contribution is family functioning. In the self-efficacy variable, the indicator with the highest contribution is generalization. Thus, in an effort to increase entrepreneurial interest, these indicators are prioritized for improvement.

\section{Limitations and Future Research}

This study was only conducted in the environment of the faculty of economics, business, and tourism at the Hindu University of Indonesia. In the future, research needs to be done besides cross-faculties, it can also be done across universities, in order to obtain more precise conclusions. In addition, interest in entrepreneurship can actually be influenced by various factors both internally and externally of individuals. Therefore, to get a better picture, it is necessary to integrate a number of other relevant variables in relation to entrepreneurial interests.

\section{REFERENCES}

Aladejebi O. (2018). The Effect of Entrepreneurship Education on Entrepreneurial Intention among Tertiary Institutions in Nigeria, Journal of Small Business and Entrepreneurship Development, Vol. 5, No. 2, pp. 1-14

Arshad, M., Farooq, O., \& Farooq, M. (2019). The effect of intrinsic and extrinsic factors on entrepreneurial intentions the moderating role of collectivist orientation, Management Decision, 0025-1747

Ayyubi A.U.A., Setyanti S.W.L.A., Suroso I. (2018). The Role of Self Efficacy as Mediating the Influence of Family Environment and Social Environment on Student Entrepreneur Interest, International Journal of Scientific \& Technology Research Volume 7, pp. 33-39

Bandura, A. (1997). Self-Efficacy: The Exercise of Control. New York.

Bartlett, S., \& Burton, D. (2016). Introduction to education studies. Sage.

Braag, S., \& Henry, N. (2011). Order 121-Study on Support to Indicators on Entrepreneurship Education. Framework Contract No. EAC, 19(06).

Brannen, J. (2019). Social Research Matters: A Life in Family Sociology. Bristol University Press. 
Campo J.L.M. (2011). Analysis of the influence of self-efficacy on entrepreneurial intentions Analisis de la influencia de la auto-confianza en las intenciones emprendedoras, Prospect. Vol. 9, No. 2, pp. 14-21

Chipman, S. F., Segal, J. W., \& Glaser, R. (2013). Higher cognitive goals for education: An introduction. In Thinking and learning skills (pp. 13-30). Routledge.

De Mooij, M. (2019). Consumer behavior and culture: Consequences for global marketing and advertising. SAGE Publications Limited.

Deliana, M., Rahardjo, K., Afriyanti, T. W. (2019). Influence of Business Education on Entrepreneurial Intention with Feasibility and Entrepreneurial Self-Efficacy as Intervening Variables. Jurnal Bisnis dan Manajemen, 20(2), 125-135.

Dogan, E. (2015). The effect of entrepreneurship education on entrepreneurial intentions of university students in Turkey. Ekonometri ve Istatistik e-Dergisi, (23), 79-93.

Franco, M. (Ed.)., 2016. Entrepreneurship: Practice-oriented Perspectives. BoD-Books on Demand.

Fuller B, Liu Y, Bajaba S, Marler L E and Pratt J. (2018). "Examining how the personality, self-efficacy, and anticipatory cognitions of potential entrepreneurs shape their entrepreneurial intentions," Personality and Individual Differences 125 p 120-125

Gautam, M. K., \& Singh, S. K. (2015). Entrepreneurship education: concept, characteristics and implications for teacher education. An International Journal of Education, 5(1), 21-35.

Hajrah S. B. B., \& Rahayu W. P. (2016). Effect of Entrepreneurial Education and Economic Condition of Parents Towards an Entrepreneurship Attitudes through the Entrepreneurship Interest. Journal of Business and Management, 18, 106.

Harackiewicz, J. M., \& Hulleman, C. S. (2010). The importance of interest: The role of achievement goals and task values in promoting the development of interest. Social and Personality Psychology Compass, 4(1), 42-52.

Hattab, H. W. (2014). Impact of Entrepreneurship Education on Entrepreneurial Intentions of University Students in Egypt. Journal of Entrepreneurship, 23(1), 1-18

https://nasional.kompas.com/read/2018/04/05/17261391/jumlah-entrepreneur-diindonesia-jauh-di-bawah-negara-maju-ini-kata-jokowi

Hutagalung B., Dalimunthe D.M.J., Pambudi R., Hutagalung A.Q., Muda I. (2017). The Effect of Enterpreneurship Education and Family Environment Towards Students' Entrepreneurial Motivation, International Journal of Economic Research, Volume 14, No. 2, pp. 331-349

Hutasuhut, S. (2018). The Roles of Entrepreneurship Knowledge, Self-Efficacy, Family, Education, and Gender on Entrepreneurial Intention. Dinamika Pendidikan, 13(1), 90105.

Hutchison, E. D. (2018). Dimensions of human behavior: Person and environment. Sage Publications. 
Kalantzis, M., \& Cope, B. (2012). New learning: Elements of a science of education. Cambridge University Press.

Kuratko, D.F. (2016). Entrepreneurship: Theory, Process, and Practice; Cengage Learning: Boston, MA, USA.

Lai, C. (2015). Entrepreneurial Knowledge and the Influence of Entrepreneurship Education on Students' Entrepreneurial Abilities. Open Journal of Social Sciences, 3(07), 1.

Lekoko, M., Rankhumise, E. M., \& Ras, P. (2012). The effectiveness of entrepreneurship education: What matters most? African Journal of Business Management, 65(1), 12023.

Mardisentosa, B., \& Mulyasana, D. (2018). Entrepreneurial interest at University's student in Tangerang City: educational entrepreneurship, famliy and personal characteristics. Nusantara Education Review, 1(1), 1-16.

Melville, H., Bryant, J., \& Haskell, S. (2007). Springer. Moby-Dick: a Longman Critical edition.

Mitra, J. (2019). Entrepreneurship, innovation and regional development: an introduction. Routledge.

Mwasalwiba, E. S. (2010). Entrepreneurship education: a review of its objectives, teaching methods, and impact indicators. Education+ training.

Naktiyok, A., Karabey, C. N., \& Gulluce, A. C. (2010). Entrepreneurial self-efficacy and entrepreneurial intention: the Turkish case. International Entrepreneurship and Management Journal, 6(4), 419-435.

Novita A. D. A., Irawan, B. S., Stefani D., Sari (2017). The Effect of Self Confidence, Quality Education and Family Environment on Indonesian Youth in Entrepreneurship, The Effect of Self Confidence, Quality Education and Family Environment on Indonesian Youth in Entrepreneurship, Vol. 1, No. 1, pp. 29-40

Nurmaliza C., Indrawati H. (2018). Analysis of Factors Affecting Entrepreneurial Interest of Vocational High School Students in Pekanbaru, Journal of Educational Sciences. Vol. 2, No. 2, pp. 42-51

Patricia, Silangen C. (2016). The Effect of Entrepreneurship Education on Entrepreneurial Intention in Indonesia, DeReMa Jurnal Manajemen Vol. 11 No. 1, pp. 67-86

Periansya (2018). Analysis of Effect of Education Entrepreneurship and Family Environment Towards Interest Students Entrepreneurs, Jurnal Terapan Manajemen dan Bisnis, Volume 4 Number 1, Page 25-32

Pihie, Z. A. L., \& Bagheri, A. (2013). Self-efficacy and entrepreneurial intention: The mediation effect of self-regulation. Vocations and Learning, 6(3), 385-401.

Prianto A., Zoebaida S., Sudarto A., Hartati R.S. (2018). The Effectiveness of an Entrepreneurship Learning Modelin Growing Competence and Entrepreneurial Intention of Vocational High School Students in East Java Indonesia, International Journal of Humanities and Social Science Vol. 8 • No. 8, pp. 199-209 
Provinsi Bali Dalam Angka (2019), Badan Pusat Statistik, Bali

Rachmawan, A., Lizar, A. A., \& Mangundjaya, W. L. (2015). The role of parent's influence and self-efficacy on entrepreneurial intention. The journal of developing areas, 417-430.

Rothstein, R., \& Jacobsen, R. (2006). The goals of education. Phi delta kappan, 88(4), 264-272.

Sadriwala K.F., Kan L.A.A. (2018). Entrepreneurial Self-Efficacy and Its Impact on Entrepreneurial Intention, International Journal of Management Sciences and Business Research, Sep-2018 ISSN (2226-8235) Vol-7, Issue 9, pp. 9-22

Sandi, A., \& Nurhayati, M. (2020). Effect of Entrepreneurship Education, Family Environment and Self-Efficacy on Students Entrepreneurship Intention. In 4th International Conference on Management, Economics and Business (ICMEB 2019) (pp. 9-12). Atlantis Press.

Santoso, S., \& Oetomo, B. S. D. (2018). Influence Of Motivation And Self-Efficacy On Entrepreneurial Intention To Run A Business. Expert Journal Of Marketing, 6(1).

Saraih U.N., Aris A.Z.Z., Mutalib S.A., Ahmad T.S.T., Abdullah S., Amlus M.H. (2018). The Influence of Self-Efficacy on Entrepreneurial Intention among Engineering Students, The Influence of Self-Efficacy on Entrepreneurial Intentional among Engineering Students, MATEC Web of Conferences 150, 05051, pp. 1-6

Shaheen N., Haddad S.A. (2018). Entrepreneurial self-efficacy and entrepreneurial behavior, International Journal of Development and Sustainability, Volume 7 Number 10, pp. 2385-2402

Slavin, R. E. (2019). Educational psychology: Theory and practice.

Sudjarwo R., Wahyudin A., Sudarma K. (2019). The Role of Self-Efficacy in Mediating the Effect of Entrepreneurial's Knowledge, Personality and Family Circles Against the Enterprise's Interest, Journal of Economic Education, 8 (1), pp. 67 - 74

Wiani A. Anita, Ahman E., Machm A. (2018). Effect of Family Environment on Interest in Entrepreneurship Students SMK in Subang Regency, Oikos: Jurnal Kajian Pendidikan Ekonomi dan Ilmu Ekonomi, ISSN Online: 2549-2284, Volume II Nomor 2, pp. 122-132 